\title{
Decriminalization of Drugs: An Alternative to Decrease Brazilian Violence?*
}

\author{
Maria Stela Grossi Porto ${ }^{1}$, Welliton Caixeta Maciel $^{2}$ \\ ${ }^{1}$ Department of Sociology, University of Brasilia, Center for the Study of Violence and Safety, \\ University of Brasilia-NEVIS/UnB, Brasilia, Brasil \\ ${ }^{2}$ Center for the Study of Violence and Safety, University of Brasilia-NEVIS/UnB, Brasilia, Brasil \\ Email: msgrossi@unb.br, wellitonmaciel@unb.br
}

Received October 1, 2013; revised November 1, 2013; accepted November 10, 2013

Copyright (c) 2014 Maria Stela Grossi Porto, Welliton Caixeta Maciel. This is an open access article distributed under the Creative Commons Attribution License, which permits unrestricted use, distribution, and reproduction in any medium, provided the original work is properly cited. In accordance of the Creative Commons Attribution License all Copyrights (C) 2014 are reserved for SCIRP and the owner of the intellectual property Maria Stela Grossi Porto, Welliton Caixeta Maciel. All Copyright (C) 2014 are guarded by law and by SCIRP as a guardian.

\section{ABSTRACT}

In Brazil, the issue of violence can be thought by two dimensions of significant proportions, drug trafficking and use and weapon trafficking and licensing. The increase of these activities, due to the involved content of violence, cruelty, and transformation of evil into a routine, is amongst the phenomena that multiply fear and the feeling of insecurity with which some Brazilian cities live currently. The backdrop of the following reflections is the Federal District, used as an example of some of the issues to be addressed. The figures involving drug possession, use, and trafficking in the Federal District have been increasing significantly, be it considering the perpetrators or the crimes, and these data are strictly related to the increase in violence in the region; its roots are multiple and complex making it impossible to explain through linear causal relations. One argument that we would like to focus here considers that if the decriminalization of drugs occurred and a countless amount of activities that currently took place in the underworld of invisibility, within the logic of terror, fear, accusation, and inhumanity were introduced into the market and regulated competition, the current violence indexes could decrease. The ones who are in favor of this argument are also willing to admit the difficulties to evidence it due to precarious amounts of information and data available, as a consequence of the illegal characteristic of the activities involved. Summing up, it can be said that the data presented and the arguments derived from these data give empirical and theoretical support to the argument in favor of broadening the knowledge and the debate about the possibility, the effects and the consequences of bringing, in a still undefined future, activities involving drug use and trafficking into legality.

\section{KEYWORDS}

Violence; Drug and Weapon Trafficking; Decriminalization of Drugs; Public Safety; Public Polices of Health

\section{Introduction}

Amidst the plurality of feelings involved in the issue of violence, one observation seems constant when referring to the almost homology between fear and violence. The growth of both is addressed along with their relevance within the Brazilian urban context. Circumscribed initially to the major metropolis, it reaches, however, me-

\footnotetext{
"Paper originally presented in the First ISA Forum of Sociology, Barcelona/Spain, September 5-8, 2008; developed within Research Project supported by CNPq.
}

dium-sized and even small cities equally. That is, violence and its consequent fear are addressed as if they were an endemic issue that has been spreading more or less without control. The idea takes the shape of a clamor for public safety understood as a synonym of a set of measures, actions, and interventions. They are all carried out by the state to reduce violence and reproduce standards of greater solidarity. Among myths, truths, and misunderstandings, violence and safety form a conceptual pair through which violence is the increasingly present phantom that attacks and undermines safety. As a 
consequence, it results in a crisis situation.

In Brazil, the issue of violence is strictly represented by two other dimensions of significant proportions, drug trafficking and use and weapon trafficking and licensing. The increase of these activities, due to the involved content of violence, cruelty, and transformation of evil into a routine, is amongst the phenomena that multiply fear and the feeling of insecurity with which some Brazilian cities live currently.

In relation to weapons, which are not the objects of this article, the Referendum on Disarmament, answering "yes" or "no" to the question: "Should fire weapons and ammunitions trade be prohibited in Brazil?” took place on October 23, 2005. The population manifested itself against the prohibition of firearms trade, contrary to what seemed to be the wish of the majority, a result that points towards the major problems in the writing of the referendum question. As a result, it also pushes further away the reduction of fatal conflicts that could have resulted from the decrease of weapons available to the common citizen. The profitable weapons industry has won.

In the case of legislation on drugs, law 11,343, a new law approved on August 23, 2006, revokes the previous laws 6368 of October 21, 1976 and 10,409 of January 11, 2002. It "establishes the Sisnad-National Public Policies System on Drugs; it drafts measures for the prevention of improper use, care, and social reinsertion of drug users and addicts; it establishes norms to repress the unauthorized production and illicit trafficking of drugs; it defines crimes and takes other measures”"

Despite the Brazilian legislation is based on the American model of repression to war against drugs and a therapeutic treatment to the user and addict, the basic structure has not been created yet for the efficient implementation of those measures [1].

Considering the inter-relation among public safety, violence, and drugs, the best equation of efficient policies in public safety is not separate from the ways of addressing the drug issue, weapons trafficking and licensing. The three of them together contribute to innumerous social representations, manifestations and practices of violence within Brazilian society. Due to the content implicit in the law, its approval has been the object of much controversy and debate. Questions refer to many aspects but, mainly, to technical problems, especially considering the legal aspects and problems of a substantial or moral nature. They question the most philosophical content linked to the adequacy of the law. Manifestations come from civil society and public sectors involved or responsible for public safety activities (Police Corporation, for example). From the technical point of view, one of the issues raised refers to the implications and consequences

${ }^{1}$ Office of the Chief of Staff of the Presidency, Undersecretary for Legal Matters. of the law in relation to the decriminalization versus legalization of drugs. Another issue refers to the identification of competent institutions to discuss the matter, considering the scientific characteristic of the knowledge required to define what is drug, addiction, etc. The moral issue changes verdicts of good and evil into absolute and concentrates on the judgment of users. Doing this way, it stigmatizes the individual, defining him/her as a deviant [2] of socially approved behavioral standards. This is a judgment that interferes in the assessment or analysis of the legislation stricto sensu.

From a sociological point of view, we would like to argue that part of the meaning implied in the interpretation of this legislation is the result of social representations, understood as: " $a$ form of socially elaborated and shared knowledge with a practical objective that contributes to the development of a reality common to a social group" [3].

Representations are biased with values, especially related to the user and the ways to consider him/her, giving the privilege through the biological perspective to addiction understood as a disease, and in the penal perspective, as an infraction or a crime. These representations and the values they imply, inform and interfere in the way that civil society and people involved in law interpretation and enforcement assess it. Some hypothesis can be valuable in the development of arguments.

One argument that we would like to focus here considers that if the decriminalization of drugs occurred and a countless amount of activities that currently took place in the underworld of invisibility, within the logic of terror, fear, accusation, and inhumanity were introduced into the market and regulated competition, the current violence indexes could decrease. The ones who are in favor of this argument are also willing to admit the difficulties to evidence it due to the precarious amounts of information and data available, as a consequence of the illegal characteristic of the activities involved.

It was said that the decriminalization would benefit health and public safety and not merely economic transactions. What is most relevant from a sociological perspective is the possibility of contributing to a change in the content of social relations themselves.

For instance, [4] says about this:

"By transforming drug use into a police matter, the State loses complete control over the cycle of the commercialized product. Legalization, on the other hand, allows the health surveillance agencies to control the quality of the products manufactured and commercialized, avoiding greater damage to be made. This is how it works in the case of alcoholic beverages distilleries, tobacco industries, etc. But in the case of illicit drugs, nobody has any sort of control over what is mixed into what is sold, for example, as marijuana or cocaine. According 
to the law, the drug dealer who sells pure cocaine is as much a criminal as the one who mixes it with powder of chalk, marble or glass, which is completely absurd in terms of public health.”

Thus, it can be assumed that in the absence of minimal control, the underworld involved in the illegal commerce of drugs, with its close connections to the use and illegal traffic of weapons and corruption may end up escalating the level of violence, crime and deviance.

The backdrop of the following reflections is the Federal District, DF, which is used as an example of some of the issues to be addressed. The statistics and data presented here were collected in academic articles or taken from websites of the MJ-Ministry of Justice in Brazil, the Public Safety Secretariat in the DF (Federal District), the CODEPLAN_-Planning Company of the DF, and the coverage over a period of two months of the newspaper “Correio Braziliense” on drug trafficking.

\section{Violence, Fear, and Drugs}

Some of the social representations of the DF-Federal District urban context-include phrases such as, "Brasilia is no longer the same" or "It is a Fantasy Island". An island wich is filled with fear and insecurity, moving into an urban chaos no different from other large and medium-sized cities. These ideas have become common to the citizens of the city, characterizing one of many stereotypes that define the city and with which its citizens live. This fact makes it difficult to perceive that the federal capital, just like another region in the country, is a space filled with ambiguities, heterogeneity, inequalities, and paradoxes.

When considering issues of public safety, the DF has a privileged situation. Its administrative organization, with an absence of municipal authorities, minimizes, although does not eliminate, conflicts similar to those that occur in other states between mayors and governors due to the centralization of the political coordination of the Safety Secretariat of the DF.

According to the data from SENASP-National Public Safety Secretariat, Brasilia is the unit in the federation with the largest ratio of police officers to population: "In 2003, the DF had one military police officer for every 137 inhabitants, a figure much lower than the national average (453 inhabitants); when compared to other countries, the figure is also equivalent” [5]. In budgetary terms, this privilege repeats itself in wages; a police officer in Brasilia can be paid up to three times more than a police officer in Rio de Janeiro. According to the data from the Correio Braziliense, on October 21 2007, provided during an interview to the newspaper of a commanding officer from the BOPE-DF-the Special Operations Force of the Federal Distrit, a police officer in Rio de Janeiro is paid $\mathrm{R} \$ 900.00$ and an officer in Brasilia is paid
$\mathrm{R} \$ 3500.00$. These figures seem to suggest a privileged situation also in terms of violence and crime rates in the DF. Yet, the data do not demonstrate this.

Different scenarios have contributed to the development of fear and insecurity as recurrent representations of the urban panorama of the city. Emblematic cases of police violence; crime with elevated levels of cruelty carried out by youth of distinguished socioeconomic segments; repeated situations of gang violence; and scenes of interpersonal violence such as, neighbor disputes and domestic violence against women and children in various socioeconomic and cultural levels have inserted the Federal District into the group of the most violent cities in the country. Yet, it is the growing coordination between drugs and weapons, including trafficking, consumption, and smuggling, for which the safety system feels completely unprepared, that have recently transformed Brasi$\mathrm{lia}^{2}$ in the center of attention, multiplying the culture of fear, especially in the surrounding regions.

The "Correio Braziliense", the most important newspaper in the city (approximately 70,000 daily editions), published, between September and October, 2007, a series of articles entitled "Trafficking, Extermination, and Fear". These articles expose the central aspects of violence linked to drug trafficking and the frailty to which the population in the surrounding areas of the city is exposed to and its consequences for the entire region. The newspaper itself and the region found themselves at the epicenter of a storm and receiving national and international attention when one of the journalists responsible for the articles was shot, precisely at one of these surrounding cities, Cidade Ocidental, during his investigative work, pointing towards an attempted murder. The police from Goiás, however, before concluding the inquiry, believed it to be a robbery. This inference ended up causing the dismissal of the detective responsible for the investigation and hasty statements. At the time, the NGO "Reporters without Borders" and the State Assembly Human Rights Committee noted the challenges of investigative journalistic coverage and called attention to an aggravating circumstance: the participation of police in organized crime: The committee chairman and also deputy of this Assembly, based on the studies of processes and reports received, stated (on September 21, 2007, in the Correio Braziliense), the existence of a very high percentage of police officers directly or indirectly involved in organized crime, especially drug trafficking. This deputy also stated that the increase in crime in the surrounding cities was not a recent phenomenon and the abandonment of that region only ceases when something serious occurs, such as this crime against the journalist. At such times emergency measures are proposed and, in

${ }^{2}$ Brasilia is limited to the pilot plan, basically an airplane in the original plan. The DF includes this area and the so-called satellite cities. 
most cases, they are never even implemented.

In explosive situations such as this, it is common to argue for the existence of a crises within the public safety system, attributing its reasons to the lack of human and material resources, the low procedural efficacy, ineffective actions, the need to modernize procedures and routines, precarious training of professionals, low wages, growing levels of police violence, impunity, and a coordination that points towards the inexistence of structural reasons and circumstances.

If, parallel to such crises diagnosis, some brutal manifestation of violence, led by representatives of the civilian population or the state apparatus, provokes a state of shock and/or popular commotion, bringing the debate between inhumanity and civilization back to life. In such cases, it is common that the State responds using an emergency plan. This includes promises to increase the transfer of funds (conditioned, of course, to specific countermeasures in terms of goals, specific practices and actions to reduce violence) and even to change proposals that require a legislative process, with the production of new legislation and/or increase or hardening of the existent penalties. Thus, problems are attributed to the insufficiency of law and solutions to the prevalence of a punitive State. These measures try to reinforce the efficacy of police action and ensure a certain decrease of fear and insecurity that takes over the population at such times.

This is what happened after the attempted attack on the journalist, when the arrival of the National Public Safety Force $^{3}$ in the region was presented as an emergency solution for the problems in the surrounding cities. This fact generated a considerable amount of controversy: on the one hand, the National Force was called by the DF government, on the other, its presence depended on the request of the Goias government state where the surrounding cities are located, and which was delaying such request not to demonstrate frailty.

Along with the debate as to whether or not the Force should be called, the idea of calling this National Force, despite the state of emergency, reveals a concept of confrontation of traffic, violence, and crime, with a philosophy of war and combat instead of policies guided towards prevention and long term actions. Polices which include the preparation and training of police force and urban policies provide the region with minimal urban equipment such as school, leisure, health, amongst others. This belligerent philosophy partly explains the absence of unanimity as to the presence (which in fact did occur) of the National Force in the surrounding cities. Another

\footnotetext{
${ }^{3}$ Force created in 2004 formed by military police officers and firefighters named by the security secretariats of their states of origin. It is called by request of a state government during states of emergency. It is meant to act as part of the actions of the PRONASCI-National Safety Program with Citizenship, of the Ministry of Justice, with 6.7 billion in funds to combat violence.
}

aspect of the controversy had to do with administrative issues: who takes the responsibility, who provides a lodge and where the police force is going to be lodged, amongst other bureaucratic matters. The arguments against the use of the National Force do not deny that a crises situation might demand emergency measures, but rather question the adequacy and competency of this Force in police work for daily routine practice, for the preventive nature required by most interventions with the aggravating circumstance of working in an unknown environment.

Yet, the biggest problem in terms of Public Safety in situations such as those mentioned in the surrounding and satellite cities of the DF is precisely the absence of a policy or, in other words, of medium and long term planning. The public security has been used to the actions taken after the problems have happened as to find solutions for them. In summary, to say it in an abrupt and brutal manner, this is how the presence of the federal forces, or Elite Troops, in the surrounding cities occurs. The assumption is that its work will be the solution and salvation to violence, crime, and drugs in the DF, when, in fact, it has another role and is not prepared for this daily action. Its permanence for long periods of time (as it has been occurring in the surrounding cities of the DF) is not in accordance with its role, which is for emergencies.

Other data is relevant to better understand the situation of the DF and its surrounding cities. The DF currently has a population of 2,051,146 inhabitants distributed in 19 administrative regions, including 11 satellite cities. Of these, some, like Taguatinga, have a population greater than Brasilia. The satellite cities have a total of 1,200,000 inhabitants and Brasilia has the other 200 thousand inhabitants.

The surrounding area is formed by 19 municipalities from the states of Goiás and Minas Gerais, of which 6 are considered the most violent cities in the region. Some are located very close to the DF, 40 - $70 \mathrm{~km}$ away from Brasilia. In the last ten years, these cities have had a considerable increase in population (according to what has been estimated in the 2000 census, presented by the Correio Braziliense, only one of these cities grew less than $50 \%$ during this period), without a corresponding countermeasure in urban equipment. With the exceptions of Luziânia, created in the $17^{\text {th }}$ century (1833), Cidade Ocidental, created in 1993, and S. Antonio do Descoberto, created in 1982, the other cities are recent, created in 1997. They all have high growth rates and absolute precariousness in terms of dignified urban life conditions. However, what, in fact, inserted them into the statistics and introduced them into the media on violence is their growing association to drugs and weapons trafficking, transforming the surrounding region into an explosive 
and dangerous one, motivating their insertion into the regions to be benefited by PRONASCI ${ }^{4}$ funds.

This surrounding region is heterogeneous; it is also formed by cities with low potential danger and low crime rates. Additionally, this region legally belongs to the state of Goiás but is in fact inserted in the Federal District since most cities are dormitory cities, with a population that is dependent of the DF linked to employment and urban equipment, such as safety, health, leisure, and education. The governments of both regions are in conflict related to the assignment of duties and responsibilities and the flaws and guilty parties for the political administrative emptiness existent in the region.

Already called "baixada federal" 5 , the region is controlled by drug dealers who share space and power and spread fear and insecurity to such an extent that even the Ministry of Planning has recently declared that the IBGE - the Brazilian Geography and Statistics Institute, was unable to collect data there, for lack of access to the area. That is, the state is absent and the organized crime expands its control. The situation is a replica of what occurs in other capitals and regions in the country: when arrests are made, they affect the intermediaries and, especially, the minor criminals, frequently, adolescents. Their position as dealers, or retail dealers, as those who sell drugs in the streets are often called, transform them into the preferential victims of confrontation, either being with the police (some also involved in trafficking) or rival traffickers. This fact makes the prisons crowded, without reaching the epicenter of the problem, since the major drug dealers are still free ${ }^{6}$, enjoying the profits of their illegal activity. Little is known about these characters that profit from crime: who they are, where they live, how they carry out their contacts in the underworld, and how they achieve their elevated social levels. The effects of the clandestine war can already be felt in the population that holds the criminals identified as such: "those that come from the poorest segments of the population, the ones that, because of the color of their skin are not successful" and are unable to participate in the social circles of the wealthy and legitimate businesses, the ones that carry weapons and expose themselves in the streets to the risk of facing a rival, a police officer or a better

\footnotetext{
${ }^{4}$ FPRONASCI - the National Safety Program with Citizenship, although it has preventive measures and social actions for the repression of violence, with funds in the amount of $\mathrm{R} \$ 6.7$ billion, it is still meant for emergency situations, with the selection of 11 priority zones, considered the focus of the most elevated indexes of violence in the country, amongst which, as already mentioned, it is the surrounding region of the Federal District.

${ }^{5}$ Compared to the Baixada Fluminense, in Rio de Janeiro, a region with the highest violence indicators in Rio de Janeiro.

${ }^{6}$ In terms of Brazil, Julita Lemgruber stated during a lecture given at the University of Brasilia (August 8, 2008) that $65 \%$ of the incarcerated (approximately 25,000 people) are convicted of drug trafficking, but they are, in the vast majority, small or intermediary traffickers.
}

armed victim [6]. Precisely because these are not the major drug dealers, their arrest or death does not come close to the center of the problem. The drug world reserve army is vast and its potential turnover is also huge.

This is one of the main arguments in favor of an analysis of the legislation that aims a view in order to improve the equation of the decriminalization/legalization of drugs. The current legislation has changed the characteristic of the penalties, with the possibility of alternative penalties, which is still not the same as decriminalization, as explained by a Law scholar [7]. The Antidrugs Law did not decriminalize the conduct of carrying drugs for personal use, as some wish, but rather lowered the punitive burden.

Just for some more information, it is convenient to mention the current Anti-project of the Penal Code. It was elaborated by the Comission of Judiciary indicated by the Congress. It contemplates the abolition of the crime linked to the drugs for personal comsumption. In the same sense, we also mention the judgement, by the Federal Supreme Court, of the Extraordinary Resource 635.659, from Minister Gilmar Mendes’ report, which is going to examine the (un)constitutionality of the article 28 from the Law 11.343/2006.

The penal sanction, as it is known, is one of the types of penalties. They can be as follows, according to clause XLVI, art. 5 of the Federal Constitution: 1) deprivation or restriction of freedom; 2) loss of property; 3) fine; 4) alternative community service; 5) suspension or restriction of rights. It can be clearly perceived that the possession of drugs for personal consumption is a crime. The change has to do with the type of penalty, which no longer deprives freedom. This, of course, can be considered a move towards a discussion of the topic as an issue of public health, applicable to norms of an administrative nature. But we have not reached this point yet.

The above mentioned series of articles published in the Correio Braziliense began on September 4 with the death of two middle class adolescents who were supposedly girlfriends of two men accused of drug trafficking involvement. The tragedy revealed a true traffic war to the general public, involving gangs, organized groups, vengeance, corruption. According to data from the newspaper investigation from March to September 2007, 41 adolescents, between the ages of 13 and 18, were killed in the surrounding region. Another 109 people, between the ages of 19 and 26, died leading the State Assembly Human Rights Committee to request funds from the Ministry of Justice for the early implementation of measures foreseen in the PRONASCI, including hiring more police officers and the already mentioned controversial participation of the National Public Safety Force in the combat of trafficking in the region.

DF Civil Police data show that 19 cities in the sur- 
rounding region have only 6 police stations and 300 civil police officers for $1,200,000$ inhabitants. It is common for cities with over 40,000 inhabitants not to have a single sheriff, as it happened in Cidade Ocidental, which remained seven months with no chief of police. This is where the attack on the journalist and the death of the adolescents took place, making the newspaper begin its investigation. CIOPs-Integrated Centers for Police Operations, substitute for police stations in most cities in the surrounding region, despite not having the necessary physical and human resource infrastructure yet. An administrative employee is present during the day forwarding the population that requires assistance to the nearest police stations around. According to an inhabitant of $\mathrm{Ci}$ dade Ocidental, as printed in the newspaper, there is no assistance during late hours. He says: "The police, here, works only until $6 \mathrm{pm}$, as if crime happens at a specific time. No one answers the phone during late hours. During a robbery, my family was held at gunpoint. I went in to report it. I banged on that door during the night and nobody opened it. I had to wait until the next $\operatorname{day}^{7}$."

During the time of the article, Cidade Ocidental, with 48,778 inhabitants, had 5 civil police officers. The gap in security also exists in the prison system. At that time, there were 7000 arrest warrants that had not been carried out, with the individuals released, amongst other reasons, due to overcrowded prisons, as the police commander of the surrounding region said to the newspaper: "If we arrested everyone we have a warrant for, we would need to open up over 10,000 vacancies in the regional prisons. The problem is that all prisons are overcrowded, there is no place for all these people". Despite the known fact that imprisonment is not the solution for part of these crimes, the minor offences, the statement does demand an analysis. Another gap refers to the amount of available police officers, on average, 1650 police officers for 1.2 million inhabitants. Similarly, the region is lacking leisure activities, education, employment, basic sanitation, etc.

Administrative disputes between the two governments in the region and the federal government itself prevent or make partnerships difficult, as it was seen with the controversial arrival of the National Safety Force. This partnership, putting together Federal and state efforts, could certainly contribute towards a positive change in the current situation, assessed as one of abandonment and absence of public power.

\section{The Data and Their Repercussions}

This article is not focused on socioeconomic stratification as a key variable, however, it is worth noting that the socioeconomic profile of consumers and even drug deal-

${ }^{7}$ Correio Braziliense, September 20, 2008. ers varies according to the type of drug considered: freebase cocaine and crack are, mainly, consumed by low income users, whereas ecstasy, LSD, and other synthetic drugs are part of the menu of users (and, often, also of dealers) of more privileged socioeconomic levels, due to their high economic value, as demonstrated by the news on drug seizure.

The involvement and death of children and adolescents in traffic, the accusations of the families of victims (who, in fear, do not identify themselves) of the involvement of police officers in drug and weapons trafficking, the use for the traffic of adolescents and models, girls who do not draw suspicion, transform this into a well known plot. The participation of middle and upper class youth, not only in the consumption but also in drug trafficking is also noteworthy, transforming them into protagonists and victims of violence.

Many authors [6,8,9-11] highlight the participation of children and adolescents in drug use and trafficking. [8] highlights the use of this young population not only as "airplanes" (name given to the adolescents who transport the drugs), but effectively as "soldiers", that is, armed staff, responsible for the order and safety of the employees who sell drugs in the communities where they live. According to [10], $70 \%$ of the violent deaths in Brazil are adolescents between 15 and 17 years of age, $50 \%$ of which would be attributed to the action of extermination groups, $40 \%$ to trafficking organizations, and $8.5 \%$ to the police. [9] highlights "Outrageous, hyperrejuvenating drug trafficking seduces an excessive group of adolescents in Latin America who, starting at twelve years of age, replace the older members. Throughout the country, the use of drugs amongst minors is increasing. Unfortunately, nowhere else in the world has the distribution of drugs been handed over to adolescents in such a routine and blatant manner as in Brazilian cities, thus, explaining the cruel murder statistics of boys and girls in such high numbers".

In the case of the Federal District, the author points out that according to CODEPLAN and Child and Social Assistance Secretariat statistics, in 1997 " $63.6 \%$ of boy and girl drug users living in the streets had already been imprisoned". This reinforces the statement of the relation existent between imprisonment and drug use and trafficking. It is important to note that this period is prior to the 2006 legislation that, in terms of penalties, did not distinguish consumption and trafficking.

According to SENASP data, the age and gender profiles available, for example, in 2004 and 2005 for the country showed that $91.6 \%$ of those convicted with possession and use of drugs are male youth and $77 \%$ are between the ages of 12 and 29 . The men considered traffickers reach $82.8 \%$ and over $50 \%$ are between the ages of 18 and 29 . When analyzed by state in the federation, 
the data on those convicted of drug possession and use highlight the states with the greatest rates as follows: Amazonas, the Federal District, and Mato Grosso do Sul, that is, border regions, with the exception of the DF, which, due to its geographic location in the center of the country, has become a strategic corridor for the distribution of drugs to the local population and other regions in the country.

Data collection was not done in the exact way for 2001-2003 and 2004-2005. The data for 2001 and 2003 include the distribution of reports registered by the Civil Police in relation to crimes involving drugs, according to the figures and rates for 100,000 inhabitants. Additionally, they inform the population and crime concentration in the capital, yet, with no distinction of age and gender. The data for 2004 and 2005 does not register crimes but rather perpetrators, both for cases of drug use and possession and trafficking, with data registered by the civil police in the federation units, including a distinction of gender and age.

Thus, if Brazil is considered as a whole group, including all regions and units of the federation, in 2003, the rate of occurrence of drug-related crimes is 57.7 crimes per 100,000 inhabitants in the center-west region. This rate is higher than the national average of 51.4 and is only lower than the rate for the southeast, 78.7, region that is inflated due to Rio de Janeiro, São Paulo, and Espírito Santo, where the capital cities have elevated drug-related crime rates. If the cities are analyzed in an isolated manner, the Federal District rate, with 90.4 drug-related crimes per 100,000 inhabitants is only lower than São Paulo, with a rate of 92.1. Rio de Janeiro, nationally and internationally associated to the highest rates of violence, crime, and homicide, in fact has a rate of 59.6 per 100,000 inhabitants of drug traffic related crimes or use and possession during the period examined.

The situation is also serious when analyzing the Federal District considering the Comparative Map of the Behavior of Report Rates per 100,000 inhabitants of Drug-related Crimes in the States in relation to the national average between 2001 and 2003. During this period, the Federal District is above the national average, which is 48.7. Additionally, these rates have been increasing between $1 \%$ and $23 \%$ during that period, along with Rio de Janeiro, Minas Gerais, São Paulo, Rio Grande do Sul, and Goiás. Only Mato Grosso do Sul has a worse situation, above the national average with growing rates of up to 69.9 during the same period.

It is important to note that the figures involving drug possession, use, and trafficking in the Federal District have been increasing significantly, be it considering the perpetrators or the crimes. Moreover, these data are strictly related to the increase in violence in the region. This increase is not an isolated fact; its roots are multiple and complex making it impossible to explain through linear causal relations, as pointed out by [6]: "The idea of cause based on successive events is inadequate. The reason is because it does not consider simultaneity and feedback, or the interactive and developed nature of the meanings attributed to what is experienced by people and what is transmitted by contamination of dissemination of ideas". Thus, with a clear emphasis on that situation that has just been mentioned and, certainly, running the risk of oversimplification, we list some of these possible roots, considering the multiple interactions involved:

1) Social inequalities and not, as it is usually stated, poverty. It would be naïve to deny that social inequalities, especially when they occur in such a perverse manner, as already pointed out, have no influence over escalating levels of violence. In that sense, they multiply situations of exclusion and marginality, increasing social distance, as it is seen in the surrounding regions where the presence of the State is almost or completely inexistent. This social distance leads illegality to become a more immediate possibility of monetary profit and affirmation for a countless group of adolescents whose minimum conditions of citizenship have been denied. Since that group is also a part of a non-regulated market, where the only existent law is dictated by force, fear, and corruption, they are in a situation where violence replaces the typical negotiations of conflicts in the formal labor market. It is, however, important to note that when establishing a direct relation among violence, poverty, and unemployment, this can lead to thinking that the poor are the only actors of violence, when it is known that they are also its main victims. The unemployed are not necessarily the majority of the prison population, despite the fact that unemployment can be an aggravating factor in situations of violence. As already demonstrated by several studies, the linearity of this relation poverty/crime is illegitimate [4-12]. Besides that, as it was pointed out by [13] the crime route follows the wealth route and not the opposite.

2) Social fragmentation leading to the fragmentation of values and violence, multiplied by the illegal market where individualism and competition prevail, especially amongst the youth, deprived from a meaning for life and, as a result, for death [14]. Some are needy for social and economic mechanisms of integration. Others, despite being inserted both socially and economically, use violence as an expression of existential exclusion: in search of identity, they use force and violence as self-affirmation mechanisms, seeking meaning and highlighting the frailty of social relations. This frailty is present in various social levels, yet the main examples of this have been violent actions accomplished by middle and upper class gangs, in episodes of cruelty and banal violence. Those episodes reveal the absence of the acknowledgement of 
the "other" as an individual, along with an absence of solidarity and the appearance of increasingly violent forms of socialization and conflict resolutions [15]. In the case of trafficking, dispute settlement, it involves the most varied socioeconomic levels.

3) The disorderly growth of large cities, with no accountability of governments for the provision of urban equipment. Cities are dynamic and it is expected that there will be movements in the population. The Federal District is not different, despite being chosen as world patrimony, it is not untouchable space, like an abandoned city, but quite the opposite, it is filled with life, dynamicity, and movement. Attraction and repulsion factors present in other cities are also present here. The issue is not to restrain but rather to find formula for the territorial organization to the population's movement. This means that it is necessary to address the surrounding regions that, despite being beyond the Federal District's legal borders, located in Goiás, have a population that gravitates in all senses around the federal capital, including possibilities of employment, health care, education, leisure, and, especially, public safety.

4) Finally, it is important to note that, on the one hand, drug use and trafficking are not separate from the above listed variables, since they are their root and product. On the other hand, they have their own characteristics and "organizations", rules guided by submission and control and the establishment of networks and hierarchies in a labor process that takes place in illegality, exposing the most fragile participants in the chain to risks and violence. Many of the small intermediaries responsible for selling in the streets were initially users and due to debts were inserted into commerce and illegal activities, including theft, extortion, and death.

Weapons and drug trafficking are closely related. In the drug world, weapons are substituted for law in which the strongest wins, where each one is by himself or herself. In this sense, there is pressing need to find more rigid mechanisms to reinforce the insufficient control of weapons licensing and trafficking, together with various levels of corruption: official, informal, public, and private.

For illegality to work, it demands the possibility of corruption and impunity; both are related to the work of the justice system, one of the central aspects to the problem. Cases of corruption and impunity are multiple in the socio-political-economic arena, as demonstrated by the press. In this sense, we believe that not only corruption and impunity, concretely existent and witnessed in the daily life of society, but also their representation as mundane practices, lead, even if not in an isolated manner, to unforeseeable situations where solidarity is challenged. Doing so, it may eliminate public space of discussion and negotiation of conflicts, leaving behind nothing but re- volt or violence in the horizon, as a strategy to deal with the unpredictability and chaos. Both refer to law, uses and customs, they conduct the disbelief of institutions, and lead to the suspicion of their legitimacy. A second point is that in the case of issues such as drugs and illegality, impunity and corruption are both sides of the same coin. The existence of one multiplies the exercise of the other, since the mechanisms that take to the traffic are articulated and dependent of corruption and impunity. They work in a selective manner because they only imprison the least important people, and keep the most important ones immune to the law. On the other hand, it is important to highlight that when illegal products are exchanged, the possible result is violence, as the only procedure used for the solution of conflicts due to the impossibility of using legal mechanisms to access Justice.

When analyzing only the prison aspect of the justice system, which implies leaving aside more substantial matters and concentrating the reflection only in the cost/ benefit relation, as $[16,17]$ says, the excessive imprisonment is counterproductive. It does not solve criminality while also compromising the penitentiary system. Still, as stated by the author using data from the Ministry of Justice, Brazil is increasingly imprisoning its population, going from 99.5 to 141.5 prisoners per 100,000 inhabitants between 1995 and 2001. According to these data, the Federal District, with 269.2 prisoners per 100,000 inhabitants, is in the second place amongst Brazilian states losing only to São Paulo, with a total of 276.3. The drug-related crime data for the Federal District clearly reinforces Lemgruber's arguments.

When analyzing the main aspect of drug trafficking, [18] states that adolescents are an important tool used by adult traffickers since they are protected by the Child and Adolescent Statute. They are the ones that go to the drug selling areas ("bocas de fumo") and take small amounts of drug named in Portuguese "tráfico formiguinha". While unveiling the mechanisms of traffic, the authors also identified other actors (the white collar players) or illicit activities (such as money laundering). Those actors are responsible for making illegal funds be legal. Moreover, the State often allows itself to be corrupted accepting favors (the funding of campaigns, for example). The authors conclude the following:

"It can be said that the drug trafficking mechanism is formed by: 1) individual dealers (major financiers, intermediaries, and street dealers); 2) dealers that belong to organized crime; 3 ) members of coercive institutions or state assemblies; and 4) money launderers. It is possible that there are several combinations among them or that they act simultaneously" [18].

As it was stated by [6], one example concerning those combinations, the criminals, without coming to the scene, distribute weapons to those who kill others and kill one 
another, while the responsible actors are not investigated in any way and remain invisible.

In another attempt to explain traffic, [9] calls attention to the situation of the primary sector of the economy and the low prices paid for exporting agricultural and livestock products: "By increasing the prices of exported agricultural products for farmers, it is possible that intrance of drugs in this sector might be detained."

\section{Final Considerations}

Summing up, it can be said that the data presented and the arguments derived from these data give empirical and theoretical support to the argument in favor of broadening the knowledge and the debate about the possibility, the effects and the consequences of bringing, in a still undefined future, activities involving drug use and trafficking into legality. It is very likely that, by doing so, some drugs, due to their high levels of damage to health, might have to be definitly banished; yet, this task would be one for bio-medical experts and not Law scholars or those responsible for public safety. The controversial nature of this statement is acknowledged, considering that its content is a matter of values, moral arguments, representations of good and evil, correct and incorrect. This makes it harder to have a reflection based on more technical aspects. This is going to lead to an analysis that, from a sociological perspective, may keep distance from moral judgments in order to be able to analyze the social reality as it is and not as it should be.

[19] proposes "three arguments against the maintenance of criminalization of drugs: its uselessness, its incoherence, and its negative effects over society as a whole. The criminalization of drugs is useless because there is a world market for them and experience shows that markets are not abolished by Law. If there is a demand, there will always be someone ready to supply, no matter how big or small the risk involved. The prohibition of any type of product merely elevates the risks for producers, salespeople, and consumers, which leads to elevated prices, but not to the market elimination. (...) The criminalization of some drugs and not others is also incoherent because there are drugs legally produced and sold by large companies, such as alcohol, which cause devastating effects over some individuals' health, family life, and even the community. Tobacco also produces highly negative effects over its consumers, despite not provoking the same type of behavioral disorder as alcohol. (...) The negative effects over public health end up burdening the health system as well. Society will have to pay the cost of treating drug addicts with not a single cent having been collected throughout the drug production and distribution chain. As for the effects over public safety, these are very well known. Similarly to the prohibition of the gambling ("jogo do bicho"), which drew those involved in the game closer to drug traffickers, drug traffickers have now associated themselves to other much more dangerous crimes, such as weapons trafficking, cargo theft, etc. Additionally, everybody involved in the huge traffic network is outside the realm of protection of the State and transformed into hostages of "crime lords". If fighting against traffic is impossible, fighting against crime is not."

With legal and psycho-social arguments, [20] points out that the current public policy philosophies about drugs tend to go in two directions: one is the criminalization of the user, with an emphasis on the penal aspect of the State, the other is the decriminalization of the drug, but, at the same time, it makes the user pathologized. He says that another change in focus would be to question social determinants instead of individual ones that lead to drug consumption. He says that State and Society could focus on "1) the factors that lead to the availability of drugs; 2) the cultural changes that authorize addressing the social prohibition or acceptance of drugs; 3) the modernization of terminology, taking care not to use inadequate labels to describe the relations between user and drugs and avoid classifying drugs as licit or illicit, since these labels are related to the human activity, and not to the drugs themselves; 4) the drug economy as a trade activity with broad social entrance in the market; and 5) (...) the consequences of activities linked to drugs, despite being undesirable, lead to an increase in drug use, dealer profit, corruption of state agents involved in putting these policies into operation, and the social marginal cost of drugs, which has been paid for, and will continue to be paid for by society, of course. In addressing these five points, society and State would take effective actions to reduce the damage consequence of drug use."

In an article written at the time of the presidential veto to the 2002 legislation, $[16,17]$ calls attention to the need for setting hypocrisy aside and the initiation of a serious debate on the decriminalization of drug use and trafficking. "To set hypocrisy aside is, above all, to admit that the policy of war against drugs that emphasizes repression has failed. It has failed in the United States; it has failed everywhere, including Brazil." She makes note of the fact that the cost of the war on drugs in the United States reached US\$18 billion, in 2000. There is a wide access; high school students state that buying drugs is more easily than alcohol. Moreover, the number of deaths due to licit drugs, alcohol and tobacco, is higher than illicit ones. Just like Brazil, the imprisoned for possession or trafficking are not the most important traffickers but the small dealers who are the targets of repression, retaliation, and violence.

$[16,17]$ also points out that "the international illicit drug market is a US\$400 billion a year market, or $8 \%$ of 
the total global trade, generating astronomical profit, corrupting police and politicians, provoking a cycle of violence that has reached alarming levels in various countries, and it is far from being defeated by means of repression."

In the last years countries in different regions of the world have assumed several propositions in relation to the war on drugs. In the USA, the medical use of marijuana is regulated by Law in various states. This idea of the coming up of marijuana as a medical device has arrived in many of those states as a popular initiative. In 2009, the Supreme Courts from Argentina and Colombia understood that the Penal Law does not own legitimacy to frame the personal drug consumption as a criminal offence since the selfinjury can not be considered one reason for incrimination. That means, the decriminalization, among other arguments, is based on the defense of the right for privacy and private life and also on the freedom to use one's own body as a personal consumption, which results in the absence of self injury. Other countries, like Guatemala, El Salvador, Bolívia etc. have also advanced a lot in the debate related to drus. In Uruguai, the legislation which decriminalizes the possession of marijuana and controls the production, distribution and comercialization of the plant has just been sanctioned in 2013. The most used argument linked to the alternative of non prohibition is the freedom of marijuana use in small quantities. It is a model that has been adopted in several European countries like Netherlands, Portugal, Spain, Check Republic, Germany and Italy.

Including the issue of decriminalization of drugs into the debate on violence and public safety in Brazil doesn't mean stimulating consumption or admiting that violent crimes, homicides, and others of high offence levels should not be left unpunished, including the imprisonment. The idea is quite another and, in this sense, the article only intends to bring this issue to the sociological perspectives and approaches because it has not been sufficiently discussed until now. It is not the idea of being in favor of or against. This drug issue has become an important aspect of sociological work because it is an extremely important content of social representations of urban violence. If we want to understand contemporary Brazilian society, it's important to try to understand its social representations for they are contents that guide behaviors.

Based on the reality or on its social representation, different segments of society seemed to be shocked and scared by the current manifestations of cruelty and inhumanity that characterize some forms of violence. To explain or understand them is one challenge, amongst many, that instigates contemporary sociological studies. Such manifestations expose horrific and barbaric spectacles, suggesting a return to a state of nature or any oth- er stereotypes used to diagnose these new forms of violence. (Are they really new?) In addition, their growing magnitude and visibility contribute to produce this feeling of insecurity and fear, allied to the sense of threat.

Sociology would have the role, above all, to question itself on the characteristics and nature of societies in which such manifestations of violence take place and, from that point on, seek their possible causes and reasons for being individualized in some types more than in others.

Despite the seriousness of the violence here considered, the horror it produces in the most varied social segments, and its repetitive and increasing nature, we do not believe that we are living in a lost, anomic, or decadent society. That is, in a society that would be an expression of the end of times, described by biblical eschatology that would become a reality, as it can be found in some pessimistic statements informed by magically guided reasoning. On the contrary, if acts such as these, with levels of cruelty and coldness, cause repudiation and horror due to their brutality and lack of intelligibility and meaning, it is precisely because they are an exception to the rule. Banality of evil is often mentioned and the expression seems to adequately portray some crimes that attack the feelings and senses of the Federal District and Brazilian society. Yet, as long as this banal and increasingly natural evil causes such intense reactions as it has been the case, then this banality is still, to a certain degree, relative.

\section{REFERENCES}

[1] S. de Carvalho, "The Criminal Policy of Drugs in Brazil: Study Criminological and Dogmatic Law 11.343/06 (A Política Criminal de Drogas no Brasil: Estudo Criminológico e Dogmático da Lei 11.343/06),” Saraiva, São Paulo, 2013.

[2] H. S. Becker, "Outsiders, Études de la Sociologie de la Déviance,” Editions Métailié, Paris, 1985.

[3] D. Jodelet, "Représentations Sociales: Un Domaine en Expansion,” In: D. Jodelet, Ed., Les Représentations Sociales, Presses Universitaires de France, Paris, 1989.

[4] E. C. Coelho, “The Devil's Workshop and Other Studies of Crime (A Oficina do Diabo e Outros Estudos de Criminalidade),” Record, Rio de Janeiro, 2005.

[5] A. M. Costa and L. M. Bandeira, "A Brief Mapping of Field Studies on Public Safety (Um Breve Mapeamento do Campo de Estudos Sobre Segurança Pública),” In A. M. Costa and L. M. Bandeira, Eds., The Public Security in the Distrito Federal (A Segurança Pública no Distrito Federal), Editora L.G.E., Brasília, 2007.

[6] A. Zaluar, "Perverse Integration: Poverty and Drug Trafficking (Integração Perversa: Pobreza e Tráfico de Drogas),” Editora FGV, Rio de Janeiro, 2004.

[7] C. A. Volpi Filho, "Punctual Considerations about the new Drug Law (Law 11.343/2006) (Considerações Pon- 
tuais sobre a Nova Lei Antidrogas (Lei 11.343/2006))," Google Research, 2006.

[8] L. Dowdney, "From Aviãozinhos the Soldiers: The Growing Involvement of Children in Armed Groups Fighting Drug Trafficking In Rio de Janeiro (De aviãozinhos a Soldados: O Crescente Envolvimento de Crianças nas Lutas de Grupos Armados do Tráfico de Drogas no Rio de Janeiro)," In: N. V. Oliveira, Ed., Public Insecurity: Reflections on Crime and Urban Violence (Insegurança Pública: Reflexões Sobre a Criminalidade e a Violência Urbana), Nova Alexandria, S. Paulo, 2002.

[9] A. Procópio, et al., "Drug Trafficking and Human Security (Narcotráfico e Segurança Humana),” Editora LTr, S. Paulo, 1999.

[10] A. Zaluar, "Violence: Social or Institutional Issues? (Violência: Questão Social ou Institucional?),” In: N. V. Oliveira, Ed., Public Insecurity: Reflections on Crime and Urban Violence (Insegurança Pública: Reflexões sobre a Criminalidade e a Violência Urbana), Nova Alexandria, S. Paulo, 2002.

[11] A. Zaluar, "Not to Say I Did Not Speak Samba: The Riddles of Violence in Brazil (Para não Dizer que não Falei de Samba: Os Enigmas da Violência no Brasil),” In: L. M. Schwarcz, Ed., History of Private Life in Brazil (História da Vida Privada no Brasil), Companhia das Letras, S. Paulo, 2006.

[12] M. Misse, "Crime and Poverty: Old Approaches, New Problems (Crime e Pobreza: Velhos Enfoques, Novos Problemas)," In: G. Villas-Boas and M. A. Gonçalves, Eds., Brazil at the Turn of the Century (O Brasil na Virada do Século), Relume-Dumará, Rio de Janeiro, 1995.

[13] C. Beato, "Determinants of Crime in Minas Gerais (Determinantes da Criminalidade em Minas Gerais)," Brazilian Journal of Social Sciences (Revista Brasileira de Ciências Sociais), Vol. 13, No. 37, 1998. http://dx.doi.org/10.1590/S0102-69091998000200004

[14] M. Wieviorka, "The New Paradigm of Violence (O Novo
Paradigma da Violência)," Social Time, Journal of Sociology, USP (Tempo Social, Revista de Sociologia da USP), Vol. 9, No. 1, 1997, pp. 5-41.

[15] M. S. G. Porto, "Violence between Inclusion and Social Exclusion (A Violência entre a Inclusão e a Exclusão Social)," Social Time, Journal of Sociology, USP (Tempo Social, Revista de Sociologia da USP), Vol. 12, No. 1, 2000, pp. 187-200. http://dx.doi.org/10.1590/S0103-20702000000100010

[16] J. Lemgruber, “Thefts, Drugs and Hypocrisy (De Roubos, Drogas e Hipocrisia),” Centre for Studies in Security and Citizenship (Centro de Estudos de Cidadania e Segurança -CESeC), 2002.

[17] J. Lemgruber, "Crime Control: Myths and Facts (Controle da Criminalidade: Mitos e Fatos),” In: N. V. Oliveira, Ed., Public Insecurity: Reflections on Crime and Urban Violence (Insegurança Pública: Reflexões Sobre a Criminalidade e a Violência Urbana), Nova Alexandria, S. Paulo, 2002.

[18] A. Oliveira and J. Zaverucha, "Drug Trafficking: Reviewing the Bibliography and Justifying the Explanation by Mechanism (Tráfico de Drogas: Revisando a Bibliografia e Justificando a Explicação por Mecanismo),” In: Brazilian Journal of Bibliographic Information on Social Sciences (Revista Brasileira de Informação Bibliográfica em Ciências Sociais—BIBCS), No. 62, ANPOCS, Paulo, 1996.

[19] R. C. Coelho, "Why Legalize the Use of Drugs (Por Que Legalizar o Uso de Drogas)," Notices, Electronic Research, 2006.

[20] A. B. Nascimento, "A Critical View of Policies and Pathologizing Decriminalization of Drug Users (Uma Visão Crítica das Políticas de Descriminalização e Patologização do Usuário de Drogas)," Psicologia em Estudo, Vol. 11, No. 1, 2006, pp. 185-190. http://dx.doi.org/10.1590/S1413-73722006000100021 


\section{Consulted Websites}

http://www.conjri.com.br/

http://www2.camara.gov.br/comissoes/cspcco/outrasle

is.html/leisantidrogas.html

http://200.181.15.9/ccivil_03/LEIS/L6368.htm

http://www.anjt.org.br/lei1040.pdf

http://planalto.gov.br/ccivil_03/_Ato2004-2006/2006/

Lei/L11343.htm

http://www.midiaindependente.org/pt/blue/2003/02/24

7549.shtml

http://www.cultura.gov.br/noticias/noticias do dominc/i ndex.php? $\mathrm{p}=9991 \&$ more $=1 \& \mathrm{c}=1 \& \mathrm{pb}=1$

http://ultimainstancia.uol.com.br/colunas/ler_noticia.p hp?idNoticia $=33089$

http://conjur.estadao.com.br/static/text/43963,1

http://www.ucamcesec.com.br/md_art_texto.php?cod_ proj $=31$

http://www.agenciabrasil.gov.br/noticias/2008/04/30/

materia.2008-04-30.1970438918/view

http://www.luizeduardosoares.com.br/lesnovo/umanot. php?id_noticia $=13$

http://carceraria.org.br/wp-content/uploads/2012/07/L

EGALIZACAO_DE_DROGAS.pdf http://www.tribunadobrasil.com.br/?ned=2324\&ntc $=6$

$4514 \& s c=2$

http://opiniaoenoticia.com.br/interna.php?id=3956

http://conjur.estadao.com.br/static/text/41396,1

http://www.secom.unb.br/artigos/artigo.php?id=20

http://www.secom.unb.br/artigos/artigo.php?id=21

http://www.une.org.br/home3/gerais/gerais_2007/m_8 960.html

http://www.midiaindependente.org/pt/blue/2008/04/41

7823.shtml

http://www.marchadamaconha.org/blog/

Presidency: Law num. 6368, 21 October, 1976.

Presidency: Law num. 10,409, 11 January, 2002.

Presidency: Law num. 11,343, 23 August, 2006.

Presidency: Law num. 9613, 03 March, 1998.

Federal District Fire Department, Statistical dataquadriênio Jan/Apr 2007/2008.

\section{Consulted Newspapers}

Folha de S. Paulo, 08/ 04/2008.

Folha de S. Paulo, 10/19/2007.

Correio Braziliense, July to October, 2007.

Correio Braziliense, 08/05/2008. 